\title{
Animal models of cardiorenal syndrome: a review
}

\author{
Mariusz K. Szymanski • Rudolf A. de Boer • \\ Gerjan J. Navis • Wiek H. van Gilst • \\ Hans L. Hillege
}

Published online: 10 September 2011

(C) The Author(s) 2011. This article is published with open access at Springerlink.com

\begin{abstract}
The incidence of heart failure and renal failure is increasing and is associated with poor prognosis. Moreover, these conditions do often coexist and this coexistence results in worsened outcome. Various mechanisms have been proposed as an explanation of this interrelation, including changes in hemodynamics, endothelial dysfunction, inflammation, activation of renin-angiotensinaldosterone system, and/or sympathetic nervous system. However, the exact mechanisms initializing and maintaining this interaction are still unknown. In many experimental studies on cardiac or renal dysfunction, the function of the other organ was either not addressed or the authors failed to show any decline in its function despite histological changes. There are few studies in which the dysfunction of both heart and kidney function has been described. In this review, we discuss animal models of combined cardiorenal dysfunction. We show that translation of the results from animal studies is limited, and there is a need for new and better models of the cardiorenal interaction to improve our understanding of this syndrome. Finally, we propose several requirements that a new animal
\end{abstract}

M. K. Szymanski · R. A. de Boer · W. H. van Gilst .

H. L. Hillege

Department of Cardiology, University Medical Center

Groningen, Groningen, The Netherlands

\section{G. J. Navis}

Department of Nephrology, University Medical Center

Groningen, Groningen, The Netherlands

\section{H. L. Hillege ( $\square)$}

Trial Coordination Center, Department of Epidemiology,

University Medical Center Groningen, Hanzeplein 1,

9713 GZ Groningen, The Netherlands

e-mail: h.hillege@tcc.umcg.nl model should meet to serve as a tool for studies on the cardiorenal syndrome.

Keywords Cardiorenal syndrome $\cdot$ Heart-kidney interaction $\cdot$ Animal models

\section{Introduction}

Recent observations from clinical trials have enhanced the interest in the interaction between heart and kidney. Renal dysfunction has been shown an independent risk factor for the development of cardiovascular (CV) diseases [1,2] and is associated with worsened outcome in patients with hypertension [3], post myocardial infarction (MI) [4, 5], and a broad spectrum of patients with left ventricular dysfunction [6, 7]. Moreover, in chronic renal failure, CV morbidities are the main cause of mortality. Conversely, cardiac dysfunction, for instance post-MI, leads to a gradual decrease in renal function as reflected by an increase in creatinine levels [8]. This interaction between heart and kidney, where dysfunction of either one of them leads to disorder of the other, is usually referred to as the cardiorenal syndrome. It has been proposed that mechanisms of this organ crosstalk include various changes in hemodynamics, dysregulation of salt and fluid balance, endothelial dysfunction, inflammation, and activation of regulatory systems such as the renin-angiotensin-aldosterone system (RAAS), and sympathetic nervous system (SNS) $[9,10]$. The described alterations may disturb other factors and lead to a vicious circle, resulting in further structural and functional damage in heart and/or kidney. Commonly used drugs such as RAAS blockers or betablockers may affect not only the targeted system, but may also cause, via feedback loops or compensatory 
mechanisms, an increase in other factors involved in the cardiorenal interaction. However, the exact pathophysiological mechanisms behind the cardiorenal syndrome still remain unclear. The design of most clinical studies on the cardiorenal interaction does not allow drawing conclusions and explanations for the heart-kidney interaction. Alternatively, this may be achieved by well-designed animal studies. Many animal studies on cardiac or renal dysfunction have been performed and described in literature. However, the authors either did not address the function of the other organ of interest or the models they used did not mimic the characteristics of the clinical cardiorenal syndrome. There are also few animal models described, which combine cardiac and renal dysfunction. The objective of this review is to discuss these combined animal models used in studies on cardiorenal interaction. To this purpose, we will briefly describe the main pathophysiological characteristics of chronic cardiorenal failure and then discuss the available animal models. Because an adequate animal model would be instrumental for better understanding of this important clinical condition, we also discuss the need for a new model and characteristics of a new model, which would help to study the pathophysiology of the cardiorenal syndrome.

\section{Pathophysiology of the cardiorenal interaction}

Cardiorenal interaction is usually defined as a disorder of heart and kidney where dysfunction of one of the organs induces disorder of the other. Several pathophysiological mechanisms have been proposed to underlie the interaction between heart and kidney in the cardiorenal syndrome [912]. Guyton [13] described a model of complex hemodynamic connections between heart and kidney. Bongartz et al. [9] proposed a model based on Guyton's model and extended it by 4 cardiorenal connectors responsible for the progression of the cardiorenal syndrome: the RAAS, the SNS, inflammation, and nitric oxide/reactive oxygen species (ROS) balance. Hemodynamic changes are considered the main driving force in the pathophysiology of the cardiorenal syndrome. If the failing heart cannot maintain cardiac output, this results in reduction in perfusion of peripheral organs [11], including decrease in renal blood flow (RBF). Decreased renal perfusion has been shown the main determinant of reduced glomerular filtration rate (GFR) in heart failure patients [14]. Recent publications have shown that GFR reduction in heart failure patients is also inversely related to central venous pressure (CVP). In the ESCAPE trial, the only hemodynamic parameter associated with renal insufficiency was right atrial pressure [15], suggesting an important role of (renal) congestion. Increased CVP in the situation of unchanged systemic arterial pressure leads to decrease in pressure gradient across the glomeruli and subsequent decrease in RBF, but also to increased hydrostatic pressure in the kidney and subsequently to hypoxia and/or activation of intrarenal RAAS. It has been suggested that the contribution of CVP to kidney dysfunction is independent of cardiac output; however, it occurs only when forward failure is present [16]. The relationship between CVP and GFR seems to be bidirectional, as impairment in renal function may lead to salt and water retention and thus to increased venous pressures [17].

Hemodynamic changes in heart failure activate multiple regulatory mechanisms, among which the RAAS is the most important system. Initially aimed to preserve cardiac homeostasis, long-term activation of the RAAS eventually leads to the progression of HF [17], myocardial remodeling [18], and fibrosis and necrosis in the myocardium [19]. Blocking RAAS reverses histological changes in the myocardium, improves endothelial function, and reduces adrenergic tone, resulting in improved prognosis. Less is however known about the effects of long-term RAAS inhibition on renal function in HF. It may help to preserve GFR to some extent [20]; however, long-term RAAS blockade substantially disables regulatory mechanisms of the kidney [14].

Progression of heart failure leads also to compensatory activation of baroreceptors and increase in sympathetic activity. This on one hand preserves the cardiac output, but has also adverse effects such as sympathetic overdrive, cardiomyocyte apoptosis and necrosis, and arrhythmias on the long term. Sympathetic activation has been also suggested to have direct vascular effects on renal vasculature, as renal sympathetic denervation may improve GFR [21]. Moreover, the activated SNS interacts with other cardiorenal connectors, such as the RAAS [22, 23] and the oxidative stress cascade [9].

There is growing evidence that one of the connectors of the cardiorenal syndrome is oxidative stress. In heart failure patients, increased oxidative stress has been demonstrated [24] and impaired NO-mediated endothelial vasodilatation has been related to reduction in renal perfusion [25]. Lower availability of NO and increased production of ROS lead to endothelial dysfunction that has been related to reduction in renal perfusion [25], inflammation, and organ damage. Inflammation is considered a risk factor for incidence of MI and death in uremic patients [26] and a marker of severity and progression of heart failure [27-30]. Moreover, interaction between oxidative stress, inflammation, and activation of RAAS has been reported [31, 32].

Another observed phenomenon of the relationship between heart and renal failure is anemia [33]. Presence of anemia has been shown to be associated with poor prognosis in heart failure [34]. The pathogenesis of anemia in 
heart failure seems to be multifactorial and to some extent is a result of decreased renal function $[35,36]$. The combination of anemia and renal dysfunction in heart failure patients is associated with much worse outcome suggesting interaction between those two entities [37, 38]. Correction of anemia improves cardiac performance in patients with chronic kidney disease [39, 40] and both cardiac and renal function in heart failure [41, 42].

The vicious circle of pathophysiological changes in cardiorenal interaction leads to dysfunction of one or both organs, accompanied by structural changes in both heart and kidney. Pathological cardiac remodeling includes changes in tissue architecture and myocyte/capillary ratio, increased fibrosis and apoptosis, and occurs not only in response to cardiac, but also to renal stimuli. Presence of albuminuria as a sign of glomerular injury has been shown to be a strong predictor of $\mathrm{CV}$ outcome in the general population [43] and in patients with hypertension [44]. However, the pathophysiology of albuminuria and its relation with prognosis is unclear in heart failure. There is also evidence that tubular damage is present in HF population [45] and is associated with prognosis [46]. The pathophysiological mechanisms underlying tubular damage in heart failure are still unknown, but possible explanations include regional hypoxia due to decreased $\mathrm{RBF}$ and diuretic therapy.

Pathophysiological connections behind the cardiorenal interactions are presented in Fig. 1, and the most important clinical characteristics of this syndrome are summarized in Table 1.
Table 1 Pathophysiological characteristics of cardiorenal syndrome

\begin{tabular}{ll}
\hline Characteristics & Clinical manifestation \\
\hline Forward failure & $\begin{array}{l}\text { Decreased cardiac output } \\
\text { Reduced RBF } \\
\text { Increased venous congestion }\end{array}$ \\
$\begin{array}{l}\text { Backward failure } \\
\text { Neurohormonal activation }\end{array}$ & $\begin{array}{l}\text { Activation of RAAS } \\
\text { Activation of SNS }\end{array}$ \\
Oxidative stress & $\begin{array}{l}\text { Lower availability of nitric oxide } \\
\text { Increased production of ROS } \\
\text { Circulating cytokines }\end{array}$ \\
Inflammation & \\
Endothelial dysfunction & Low hemoglobin/hematocrit levels \\
Anemia &
\end{tabular}

\section{Animal models for cardiorenal interaction}

Only a few animal models have been proposed so far as a model for further studies on the cardiorenal syndrome in which both cardiac and renal dysfunction have been induced (Table 2). They are all based on the use of rodents. Advantages of small animals include lower costs, availability, and housing conditions. There are multiple ways of inducing cardiac dysfunction in rodent models. They comprise of volume or pressure overload, myocardial ischemia/infarction, administration of toxic agents, and rapid ventricular pacing. The most commonly used technique of inducing cardiac dysfunction in studies on the cardiorenal interaction is MI resulting from ligation of the left coronary artery. Main advantages of this model are
Fig. 1 Pathophysiological connections in the cardiorenal syndrome (adapted from Bock et al. [12])

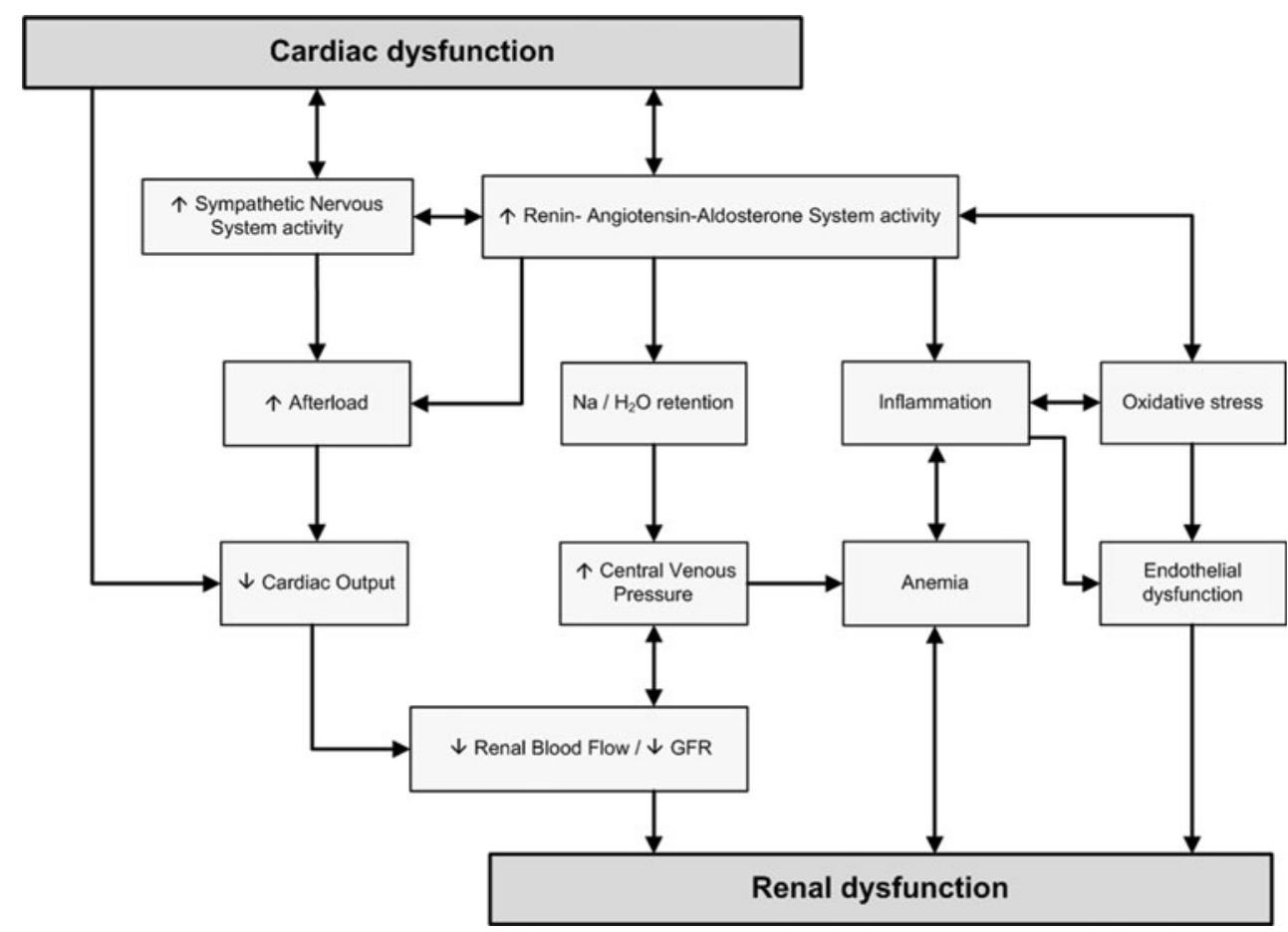


Table 2 Rodent models of combined cardiorenal failure

\begin{tabular}{|c|c|c|c|}
\hline Model & References & Cardiac changes & Renal changes \\
\hline $\mathrm{UNX}+\mathrm{MI}$ & Van Dokkum et al. [55] & $\begin{array}{l}\text { Increased SBP } \\
\text { Decreased } \mathrm{dP} / \mathrm{dt} \text { max and } \mathrm{dP} / \mathrm{dt} \min \\
\mathrm{LVH}\end{array}$ & $\begin{array}{l}\text { Increased plasma creatinine } \\
\text { Increased proteinuria } \\
\text { FGS }\end{array}$ \\
\hline $\mathrm{SNX}+\mathrm{MI}$ & Windt et al. [57] & $\begin{array}{l}\text { Increased SBP } \\
\text { Decreased } \mathrm{dP} / \mathrm{dt} \max \text { and } \mathrm{dP} / \mathrm{dt} \min \\
\mathrm{LVH} \\
\text { Decreased capillary density }\end{array}$ & $\begin{array}{l}\text { Decreased creatinine clearance } \\
\text { Decreased RBF } \\
\text { Increased proteinuria } \\
\text { FGS } \\
\text { Fibrosis }\end{array}$ \\
\hline & $\begin{array}{l}\text { Dikow et al. [62] } \\
\text { Dikow et al. [56] }\end{array}$ & $\begin{array}{l}\text { Increased SBP } \\
\text { Higher susceptibility to myocardial ischemia } \\
\text { Increased SBP } \\
\text { Decreased EF } \\
\text { Increased LVEDD } \\
\text { LVH } \\
\text { Fibrosis } \\
\text { Decreased capillary density }\end{array}$ & $\begin{array}{l}\text { Increased serum urea } \\
\text { Increased serum creatinine } \\
\text { Increased serum urea } \\
\text { Increased serum creatinine }\end{array}$ \\
\hline SNX + L-NNA & Bongartz et al. [66] & $\begin{array}{l}\text { Increased blood pressure } \\
\text { Decreased EF } \\
\text { Increased LVEDV } \\
\text { LVH } \\
\text { Fibrosis }\end{array}$ & $\begin{array}{l}\text { Increased plasma creatinine } \\
\text { Increased plasma urea } \\
\text { Decreased creatinine clearance } \\
\text { Increased proteinuria } \\
\text { FGS } \\
\text { Tubulo-interstitial injury }\end{array}$ \\
\hline Adriamycin & Noiri et al. [70] & LVH & $\begin{array}{l}\text { Increased plasma creatinine } \\
\text { Increased plasma urea } \\
\text { Decreased creatinine clearance } \\
\text { Fibrosis } \\
\text { Tubular damage }\end{array}$ \\
\hline
\end{tabular}

$U N X$ uninephrectomy, $S N X$ subnephrectomy, $M I$ myocardial infarction, $L-N N A$ N $\omega$-nitro-L-arginine, $S B P$ systolic blood pressure, $d P / d t$ max maximal rate of increase of left ventricular pressure, $d P / d t$ min maximal rate of decrease of left ventricular pressure, $L V H$ left ventricle hypertrophy, $R B F$ renal blood flow, $E F$ ejection fraction, $L V E D D$ left ventricle end-diastolic diameter, $L V E D V$ left ventricle end-diastolic volume, $F G S$ focal glomerulosclerosis

simplicity, reproducibility, and its relation to human pathophysiology. In this model, the cardiac output is significantly reduced 3-5 weeks after surgery [47] and the impairment of left ventricular function is directly related to the loss of myocardium [48]. Hemodynamic and neurohormonal changes in this model resemble those of heart failure observed in humans [49] and are also dependent on the extent of cardiac damage [50-52]. The use of the MI model has been essential in establishing the beneficial effects of RAAS blockade [53, 54], which were later confirmed in clinical trials, underscoring the agreement between this model and human heart failure with respect to the pathophysiology and treatment possibilities.

The most commonly used techniques of inducing renal failure are based on the reduction of viable kidney tissue in different ways. The main difference between them is the extent of the removal and thus the degree of renal dysfunction they cause. Unilateral nephrectomy (UNX) leads to mild renal function impairment without a substantial increase in proteinuria or histological changes [55], whereas subnephrectomy (SNX) leads to more severe renal dysfunction and eventually to uremia and chronic kidney disease complications similar as in humans [56, 57]. Changes in cardiac tissue architecture have also been reported in subnephrectomized animals [58-60].

Van Dokkum et al. [55] have described a model of UNX followed by MI 1 week later. They have shown an accelerated renal dysfunction in uninephrectomized rats when combined with cardiac dysfunction. This has been evidenced by increased levels of proteinuria. Also more renal damage, as measured by focal glomerulosclerosis, has been reported in animals with combined cardiac and renal 
dysfunction. Creatinine levels were increased, as expected, after nephrectomy; however, addition of MI did not lead to further increase. Interestingly, the decrease in renal function was more pronounced in animals with large infarcts. This might be due to the severity of cardiac dysfunction and its effect on renal hemodynamics. It has been shown that in rats after MI, the severity of ventricular dysfunction and subsequent hemodynamic changes depend on infarct size $[48,61]$ as well as time between intervention and measurements [47, 52]. Decrease in cardiac function due to small and moderate infarcts, results in either small or no decrease in RBF [50-52]. When RBF is minimally decreased, the animal upkeeps its GFR by a compensatory increase in renal vascular resistance, like in humans [51]. More severe cardiac dysfunction as a result of large infarction leads to a larger fall in RBF and a subsequent decrease in GFR despite further increase in venous resistance [51, 52]. However, the data on RBF in this model are missing, and the only indication of more severe cardiac dysfunction in the group with larger MI was more advanced hypertrophy of the heart. No differences in brain natriuretic peptide (BNP) levels, LV pressures nor contractility or relaxation between groups have been reported. The blood pressure was higher in the animals with combined damage in comparison with other experimental groups. This suggests that the compensated stage of heart failure was not present in this model. The more pronounced progression of cardiac dysfunction due to the concomitant renal dysfunction has also not been observed. However, it must be remembered that the renal damage in this model was only mild, and there was a short period of time between induction of renal and cardiac damage. This might have resulted in limited effects of renal dysfunction on heart tissue and its function.

The same group studied cardiorenal interaction in a combined model with a more severe renal dysfunction, introduced by means of SNX and 2 weeks later followed by coronary ligation [57]. In this model, the SNX induced proteinuria, decreased the creatinine clearance and increased histological changes, such as focal glomerulosclerosis, fibrosis, and mesangial matrix expansion. Introduction of the cardiac dysfunction on top of existing renal dysfunction did not influence the levels of proteinuria nor the histological changes, but led to decrease in creatinine clearance and RBF. With regard to cardiac function, combination of renal and cardiac function did not yield additional effects, different from the effects of SNX or MI alone. Animals with combined organ damage had high blood pressure, similar to the animals with renal damage alone, and decreased contractility and relaxation comparable with the animals that underwent coronary ligation only. Also, decrease in capillary density was the same as in the MI alone group, showing no effect of preexisting renal dysfunction on myocardium. This is somewhat in contrast to literature findings that showed histological changes in the myocardium of the subnephrectomized animals [58, 59]. However, again short period of time for the development of renal dysfunction and lack of signs of severe cardiac failure have to be considered. This model has also been used in studies on the effects of RAAS inhibition on the cardiorenal interaction. It has been shown that treatment with lisinopril for 6 weeks prevented further histological changes in the kidney tissue or even reversed some of them. Moreover, it restored the decreased RBF and creatinine clearance levels. It also increased capillary density and reversed the cardiac hypertrophy, proving the beneficial effects of this treatment and usefulness of this model in studies on RAAS activation in the cardiorenal syndrome.

A combined model of MI and SNX has been used by Dikow et al. [62] to study cardiac histological changes as an underlying mechanism of progression of cardiac disease in cardiorenal interaction. In this study with transient coronary ligation followed by reperfusion, it has been shown that myocardium of the rats with renal dysfunction is more susceptible to ischemia injury, which may explain the higher death rate after MI in renal patients. Whereas the total unperfused area was not different between animals with and without renal dysfunction, which would be unlikely as it reflects the anatomy of the coronary vasculature in the rat, the infarcted area was significantly higher in uremic animals. This effect was also present in animals treated with antihypertensive treatment and low- and highsalt diet, which excludes the underlying confounding effects of hypertension, sympathetic overactivity, and salt retention. The same group analyzed also the myocardial remodeling in a model of more permanent MI [56]. They have shown more advanced left ventricular remodeling in a model with cardiorenal failure as documented by left ventricular hypertrophy, decreased capillary density and increased fibrosis. Moreover, these changes were accompanied by decrease in cardiac function as assessed by echocardiography. Interestingly, the presence of anemia has also been reported in the animals with combined organ damage. This could be of special interest, since anemia is being considered one of the cardiorenal connectors [33, 63] and beneficial effects of treatment for anemia have been shown in experimental studies. In MI heart failure model, erythropoietin has been shown to improve cardiac function and induce neovascularization [64]. On the other hand, in subnephrectomized rats, anemia seemed to have protective effect on kidney structure [65]; however, this effect has not been investigated in a model with concomitant heart failure. Therefore, this model could also help to understand the role of anemia in the cardiorenal syndrome.

Bongartz et al. [66] have recently developed a new animal model of combined cardiorenal failure. This model 
is based on the hypothesis that oxidative stress and the dysbalance between nitric oxide (NO) and ROS are one of the cardiorenal connectors $[9,63]$. The inhibition of NO synthase in rats has already been shown to cause hypertension, cardiac dysfunction, and glomerular damage [67, 68]. In the MI model, oxidative stress has been proven to decrease endothelial-dependent relaxation [50], whereas antioxidant therapy prevents cardiac structure alterations [69]. In the described model, renal dysfunction has been induced by means of SNX, whereas cardiac dysfunction was a result of NOS inhibition with $\mathrm{N} \omega$-nitro-L-arginine (L-NNA). The combination of the above led to severe cardiac dysfunction with increased blood pressure, enddiastolic volume, and decreased ejection fraction. Signs of congestion, increased cardiac fibrosis, and myocyte hypertrophy accompanied the functional changes. With regard to the kidney function, the combination of SNX and L-NNA resulted in increased plasma urea and creatinine levels and proteinuria. However, only the latter was significantly higher than in animals with SNX alone. On the histological level, combined cardiorenal damage was characterized by increased FGS and tubulointerstitial injury. Interestingly, the above changes had permanent character and were not reversed even when treatment with L-NNA was stopped. This model proves the importance of oxidative stress in cardiorenal interaction and might serve as a promising tool for further investigation of cardiorenal connectors.

An alternative model, which does not require surgical intervention, is the model of adriamycin-induced renal damage. It has been shown that administration of adriamycin leads not only to deterioration of kidney function, but heart function is also affected [70]. Both cardiac and renal dysfunction resulting from adriamycin administration are characterized by many features observed in humans with cardiorenal failure-both on functional as well as on the histological level [71-73]. However, the dose required to induce the cardiac cardiomyopathy is much higher than the one resulting in severe kidney dysfunction. Therefore, the possibilities for investigation of dysfunction of both organs at the same time are limited. Moreover, it is important to mention that many of those changes are rather the effect of the toxicity of adriamycin than involvement of known cardiorenal connectors.

\section{Discussion and future perspectives}

In this review, we summarized the available data on animal models used in the studies on cardiorenal interaction. The choice of a proper model is crucial, because results obtained in experimental studies may contribute to better understanding of this important clinical syndrome and help in establishing new treatment strategies. At this moment, this translation is limited, because none of the models described above entirely reproduce the pathophysiology and characteristics of the cardiorenal syndrome observed in humans. Therefore, there is a need for better models of cardiorenal interaction that not only should mimic clinical characteristics of this syndrome by cardiac, renal, hemodynamic, and neurohumoral alterations, but also allow evaluation of the effectiveness of treatment. Such a model should consist of combined renal and cardiac injury characterized by progressive deterioration of function of both organs. With regard to the cardiac function, it should be characterized by systolic dysfunction confirmed by echocardiography or hemodynamic measurements, resulting in decrease in cardiac output and subsequent reduction in RBF. Also, increased end-diastolic pressure and venous congestion should be present in order to further investigate latest findings from clinical observations. On the histological level, cardiac injury should be characterized by hypertrophy and fibrosis and preferably with cardiomyocyte/capillary mismatch. With regard to renal injury, such a model should be characterized by a progressive decrease in renal function reflected in increased levels of creatinine and proteinuria or increased albumin excretion and decreased GFR/creatinine clearance. The presence of glomerulosclerosis and interstitial fibrosis should be documented. Important in developing a new model is to reduce the function of both organs to such a degree that leads to development of significant dysfunction as well as to provide enough time for its development. Both organ failures should also preferably develop gradually to allow studies on treatment for advanced stages as well as more preventive treatment strategies. This can help in drawing conclusions and give more insight into pathophysiology behind cardiorenal interaction on different stages of its development.

There are multiple ways of inducing cardiac $[74,75]$ and renal dysfunction [76] in rodents, which can be combined for the development of a new model of cardiorenal interaction. They all have their advantages and drawbacks, and none of them presents all the above-mentioned features of the ideal model. Most of the models require surgery intervention or administration of exogenous substances, which already reduces their similarity to the clinical situation. Furthermore, the surgical interventions, such as MI or reduction in kidney tissue, are performed on healthy organs in a situation where the regulatory mechanisms are not being activated. In humans, on the other hand, the failure is usually preceded by gradual loss of the function of chronically affected organs. The acute onset of the organ failure substrate is one of the common drawbacks that limit the clinical relevance of many popular models, such as transverse aortic constriction. An important issue in the use of animal models is also the severity of the induced organ 
failure. Moderate interventions result either in the development of mild organ dysfunction or the organ failure will develop only in a subset of the animals [48, 55, 75]. A more severe approach leads to the development of overt organ failure [48, 77], but results in high mortality rates [78] and more acute onset of the heart failure substrate. This limits the clinical relevance of such models. The usefulness of the models based on surgical interventions is also limited by the fact that they lead to significant reduction in remaining tissue mass, like in the SNX model or the MI model. This reduces the potential target and the effects of treatment, as well as possibilities for molecular analysis. Important to remember is also that the differences in response to surgical interventions have been reported between different genders [79] or animal strains [80, 81]. Above-described drawbacks of available animal models might question the possibility of designing one perfect animal model of the cardiorenal syndrome. However, it should be remembered that heart and renal failure are heterogeneous disorders that result from multiple underlying diseases and involve various regulatory mechanisms. Due to the complexity of the pathophysiology of heart and/or renal failure alone and in combination, its proper understanding might as well require the use of more than one animal model and the choice must be made depending on the research question. The heterogeneous character and origin of cardiorenal failure require also that all potential new models as well as the models already known, including those described in this review, should be studied in more detail. Not only well-established cardiorenal connectors, but also new findings in the cardiorenal interaction, such as increased venous congestion, anemia, and tubular damage need further investigation and should be addressed in these models. Only then, the usefulness of these models in studies on the cardiorenal syndrome can be evaluated.

Interesting alternative for the models described above might be the use of genetic models of cardiac and renal dysfunction. One of the biggest advantages of such models is that they do not require surgery or pharmacological intervention for induction of the disease. The onset of the stimulus for organ failure is more gradual, which allows studies on progression of the disease and prevention therapy. Well-studied genetic models of heart failure are the spontaneously hypertensive rat (SHR) [82] and the Dahlsalt-sensitive rat [83]. However, both strains require long time before they develop overt heart failure, which is their main drawback. The Munich Wistar Fromter (MWF) rats present many of the clinical characteristics of renal dysfunction [84]. However, again an extended period of time is required for the development of the renal failure. Moreover, some gender differences have been reported [85].

The genome of rodents has recently been well characterized, which provides new opportunities in finding a new better model for cardiorenal interaction. The ability of genetic manipulation offers multiple possibilities for establishing new valuable models. Knocking out or overexpression of specific genes or proteins as well as transgenesis may lead to the development of new models of organ failure [86-89]. This approach gives a good insight into role of a given gene or protein in the pathophysiology of the disease. Knock-out models can help also in understanding the pathophysiology of the diseases preceding the onset of organ failure, such as atherosclerosis [90]. However, the genetic manipulation does not allow control over the time of the occurrence or the level of intervention. Change in the expression of specific proteins may also influence their biological properties and function [91] as well as activate the compensatory mechanisms at very early stages.

\section{Conclusion}

There are only few animal models proposed for further studies on the cardiorenal syndrome. They all represent to some extent clinical characteristics of this syndrome and were used in experimental studies to better understand the pathophysiological connections between kidney and the heart. However, the heterogeneous character of heart and renal failure in humans limits the possibilities of complete reproduction of this syndrome in an animal model. Moreover, the induction of the organs failure in animals has usually an acute character, whereas heart and/or kidney dysfunction in humans usually develop over years. The recent developments in molecular techniques provide promising possibilities of developing a new animal model, which could be used as a tool for better understanding of the pathophysiology and treatment targets in the cardiorenal syndrome.

Conflict of interest None of the authors have any conflicts of interest or financial ties to disclose.

Open Access This article is distributed under the terms of the Creative Commons Attribution Noncommercial License which permits any noncommercial use, distribution, and reproduction in any medium, provided the original author(s) and source are credited.

\section{References}

1. Go AS, Chertow GM, Fan D, McCulloch CE, Hsu CY (2004) Chronic kidney disease and the risks of death, cardiovascular events, and hospitalization. N Engl J Med 351:1296-1305

2. Sarnak MJ, Levey AS, Schoolwerth AC, Coresh J, Culleton B, Hamm LL, McCullough PA, Kasiske BL, Kelepouris E, Klag MJ, Parfrey P, Pfeffer M, Raij L, Spinosa DJ, Wilson PW (2003) Kidney disease as a risk factor for development of cardiovascular disease: a statement from the American Heart Association Councils on kidney in cardiovascular disease, high blood pressure 
research, clinical cardiology, and epidemiology and prevention. Circulation 108:2154-2169

3. Mann JF, Gerstein HC, Pogue J, Bosch J, Yusuf S (2001) Renal insufficiency as a predictor of cardiovascular outcomes and the impact of ramipril: the HOPE randomized trial. Ann Intern Med 134:629-636

4. Hillege HL, van Gilst WH, van Veldhuisen DJ, Navis G, Grobbee DE, de Graeff PA, de Zeeuw D (2003) Accelerated decline and prognostic impact of renal function after myocardial infarction and the benefits of ACE inhibition: the CATS randomized trial. Eur Heart J 24:412-420

5. Anavekar NS, McMurray JJ, Velazquez EJ, Solomon SD, Kober L, Rouleau JL, White HD, Nordlander R, Maggioni A, Dickstein K, Zelenkofske S, Leimberger JD, Califf RM, Pfeffer MA (2004) Relation between renal dysfunction and cardiovascular outcomes after myocardial infarction. N Engl J Med 351:1285-1295

6. Dries DL, Exner DV, Domanski MJ, Greenberg B, Stevenson LW (2000) The prognostic implications of renal insufficiency in asymptomatic and symptomatic patients with left ventricular systolic dysfunction. J Am Coll Cardiol 35:681-689

7. Hillege HL, Nitsch D, Pfeffer MA, Swedberg K, McMurray JJ, Yusuf S, Granger CB, Michelson EL, Ostergren J, Cornel JH, de Zeeuw D, Pocock S, van Veldhuisen DJ (2006) Renal function as a predictor of outcome in a broad spectrum of patients with heart failure. Circulation 113:671-678

8. Jose P, Skali H, Anavekar N, Tomson C, Krumholz HM, Rouleau JL, Moye L, Pfeffer MA, Solomon SD (2006) Increase in creatinine and cardiovascular risk in patients with systolic dysfunction after myocardial infarction. J Am Soc Nephrol $17: 2886-2891$

9. Bongartz LG, Cramer MJ, Doevendans PA, Joles JA, Braam B (2005) The severe cardiorenal syndrome: 'Guyton revisited'. Eur Heart J 26:11-17

10. Ronco C, Haapio M, House AA, Anavekar N, Bellomo R (2008) Cardiorenal syndrome. J Am Coll Cardiol 52:1527-1539

11. Leithe ME, Margorien RD, Hermiller JB, Unverferth DV, Leier CV (1984) Relationship between central hemodynamics and regional blood flow in normal subjects and in patients with congestive heart failure. Circulation 69:57-64

12. Bock JS, Gottlieb SS (2010) Cardiorenal syndrome: new perspectives. Circulation 121:2592-2600

13. Guyton AC (1990) The surprising kidney-fluid mechanism for pressure control—its infinite gain!. Hypertension 16:725-730

14. Smilde TD, Damman K, van der Harst P, Navis G, Westenbrink BD, Voors AA, Boomsma F, van Veldhuisen DJ, Hillege HL (2009) Differential associations between renal function and "modifiable" risk factors in patients with chronic heart failure. Clin Res Cardiol 98:121-129

15. Nohria A, Hasselblad V, Stebbins A, Pauly DF, Fonarow GC, Shah M, Yancy CW, Califf RM, Stevenson LW, Hill JA (2008) Cardiorenal interactions: insights from the ESCAPE trial. J Am Coll Cardiol 51:1268-1274

16. Damman K, van Deursen VM, Navis G, Voors AA, van Veldhuisen DJ, Hillege HL (2009) Increased central venous pressure is associated with impaired renal function and mortality in a broad spectrum of patients with cardiovascular disease. J Am Coll Cardiol 53:582-588

17. Schrier RW (2006) Role of diminished renal function in cardiovascular mortality: marker or pathogenetic factor? J Am Coll Cardiol 47:1-8

18. Hirsch AT, Pinto YM, Schunkert H, Dzau VJ (1990) Potential role of the tissue renin-angiotensin system in the pathophysiology of congestive heart failure. Am J Cardiol 66:22D-30D

19. Weber KT (2001) Aldosterone in congestive heart failure. N Engl J Med 345:1689-1697
20. Ljungman S, Laragh JH, Cody RJ (1990) Role of the kidney in congestive heart failure. Relationship of cardiac index to kidney function. Drugs 39(Suppl 4):10-21

21. Krum H, Schlaich M, Whitbourn R, Sobotka PA, Sadowski J, Bartus K, Kapelak B, Walton A, Sievert H, Thambar S, Abraham WT, Esler M (2009) Catheter-based renal sympathetic denervation for resistant hypertension: a multicentre safety and proof-ofprinciple cohort study. Lancet 373:1275-1281

22. Klein IH, Ligtenberg G, Oey PL, Koomans HA, Blankestijn PJ (2003) Enalapril and losartan reduce sympathetic hyperactivity in patients with chronic renal failure. J Am Soc Nephrol 14:425-430

23. Ligtenberg G, Blankestijn PJ, Oey PL, Klein IH, Dijkhorst-Oei LT, Boomsma F, Wieneke GH, van Huffelen AC, Koomans HA (1999) Reduction of sympathetic hyperactivity by enalapril in patients with chronic renal failure. N Engl J Med 340:1321-1328

24. Heymes C, Bendall JK, Ratajczak P, Cave AC, Samuel JL, Hasenfuss G, Shah AM (2003) Increased myocardial NADPH oxidase activity in human heart failure. J Am Coll Cardiol 41:2164-2171

25. Kielstein JT, Bode-Boger SM, Klein G, Graf S, Haller H, Fliser D (2003) Endogenous nitric oxide synthase inhibitors and renal perfusion in patients with heart failure. Eur $\mathrm{J}$ Clin Invest 33:370-375

26. Zebrack JS, Anderson JL, Beddhu S, Horne BD, Bair TL, Cheung A, Muhlestein JB (2003) Do associations with C-reactive protein and extent of coronary artery disease account for the increased cardiovascular risk of renal insufficiency? J Am Coll Cardiol 42:57-63

27. Deswal A, Petersen NJ, Feldman AM, Young JB, White BG, Mann DL (2001) Cytokines and cytokine receptors in advanced heart failure: an analysis of the cytokine database from the Vesnarinone trial (VEST). Circulation 103:2055-2059

28. Rauchhaus M, Doehner W, Francis DP, Davos C, Kemp M, Liebenthal C, Niebauer J, Hooper J, Volk HD, Coats AJ, Anker SD (2000) Plasma cytokine parameters and mortality in patients with chronic heart failure. Circulation 102:3060-3067

29. Levine B, Kalman J, Mayer L, Fillit HM, Packer M (1990) Elevated circulating levels of tumor necrosis factor in severe chronic heart failure. N Engl J Med 323:236-241

30. Torre-Amione G, Kapadia S, Benedict C, Oral H, Young JB, Mann DL (1996) Proinflammatory cytokine levels in patients with depressed left ventricular ejection fraction: a report from the Studies of Left Ventricular Dysfunction (SOLVD). J Am Coll Cardiol 27:1201-1206

31. Hornig B, Landmesser U, Kohler C, Ahlersmann D, Spiekermann S, Christoph A, Tatge H, Drexler H (2001) Comparative effect of ace inhibition and angiotensin II type 1 receptor antagonism on bioavailability of nitric oxide in patients with coronary artery disease: role of superoxide dismutase. Circulation 103:799-805

32. Mezzano SA, Ruiz-Ortega M, Egido J (2001) Angiotensin II and renal fibrosis. Hypertension 38:635-638

33. Silverberg DS, Wexler D, Iaina A (2002) The importance of anemia and its correction in the management of severe congestive heart failure. Eur J Heart Fail 4:681-686

34. Lindenfeld J (2005) Prevalence of anemia and effects on mortality in patients with heart failure. Am Heart J 149:391-401

35. Anand IS (2005) Pathogenesis of anemia in cardiorenal disease. Rev Cardiovasc Med 6(Suppl 3):S13-S21

36. Westenbrink BD, Visser FW, Voors AA, Smilde TD, Lipsic E, Navis G, Hillege HL, van Gilst WH, van Veldhuisen DJ (2007) Anaemia in chronic heart failure is not only related to impaired renal perfusion and blunted erythropoietin production, but to fluid retention as well. Eur Heart J 28:166-171

37. Al Ahmad A, Rand WM, Manjunath G, Konstam MA, Salem DN, Levey AS, Sarnak MJ (2001) Reduced kidney function and 
anemia as risk factors for mortality in patients with left ventricular dysfunction. J Am Coll Cardiol 38:955-962

38. de Silva R, Rigby AS, Witte KK, Nikitin NP, Tin L, Goode K, Bhandari S, Clark AL, Cleland JG (2006) Anemia, renal dysfunction, and their interaction in patients with chronic heart failure. Am J Cardiol 98:391-398

39. Hayashi T, Suzuki A, Shoji T, Togawa M, Okada N, Tsubakihara Y, Imai E, Hori M (2000) Cardiovascular effect of normalizing the hematocrit level during erythropoietin therapy in predialysis patients with chronic renal failure. Am J Kidney Dis 35:250-256

40. Pappas KD, Gouva CD, Katopodis KP, Nikolopoulos PM, Korantzopoulos PG, Michalis LK, Goudevenos JA, Siamopoulos KC (2008) Correction of anemia with erythropoietin in chronic kidney disease (stage 3 or 4): effects on cardiac performance. Cardiovasc Drugs Ther 22:37-44

41. Silverberg DS, Wexler D, Blum M, Iaina A (2003) The cardio renal anemia syndrome: correcting anemia in patients with resistant congestive heart failure can improve both cardiac and renal function and reduce hospitalizations. Clin Nephrol 60(Suppl 1):S93-102

42. Palazzuoli A, Silverberg D, Iovine F, Capobianco S, Giannotti G, Calabro A, Campagna SM, Nuti R (2006) Erythropoietin improves anemia exercise tolerance and renal function and reduces B-type natriuretic peptide and hospitalization in patients with heart failure and anemia. Am Heart J 152:1096.e9-15

43. Hillege HL, Fidler V, Diercks GF, van Gilst WH, de Zeeuw D, van Veldhuisen DJ, Gans RO, Janssen WM, Grobbee DE, de Jong PE (2002) Urinary albumin excretion predicts cardiovascular and noncardiovascular mortality in general population. Circulation 106:1777-1782

44. Farbom P, Wahlstrand B, Almgren P, Skrtic S, Lanke J, Weiss L, Kjeldsen S, Hedner T, Melander O (2008) Interaction between renal function and microalbuminuria for cardiovascular risk in hypertension: the Nordic diltiazem study. Hypertension 52:115-122

45. Damman K, van Veldhuisen DJ, Navis G, Voors AA, Hillege HL (2008) Urinary neutrophil gelatinase associated lipocalin (NGAL), a marker of tubular damage, is increased in patients with chronic heart failure. Eur J Heart Fail 10:997-1000

46. Damman K, van Veldhuisen DJ, Navis G, Vaidya VS, Smilde TD, Westenbrink BD, Bonventre JV, Voors AA, Hillege HL (2010) Tubular damage in chronic systolic heart failure is associated with reduced survival independent of glomerular filtration rate. Heart 96:1297-1302

47. Ceiler DL, Schiffers PM, Nelissen-Vrancken HJ, Smits JF (1998) Time-related adaptations in plasma neurohormone levels and hemodynamics after myocardial infarction in the rat. J Card Fail 4:131-138

48. Pfeffer MA, Pfeffer JM, Fishbein MC, Fletcher PJ, Spadaro J, Kloner RA, Braunwald E (1979) Myocardial infarct size and ventricular function in rats. Circ Res 44:503-512

49. Francis J, Weiss RM, Wei SG, Johnson AK, Felder RB (2001) Progression of heart failure after myocardial infarction in the rat. Am J Physiol Regul Integr Comp Physiol 281:R1734-R1745

50. Feng Q, Lu X, Fortin AJ, Pettersson A, Hedner T, Kline RL, Arnold JM (1998) Elevation of an endogenous inhibitor of nitric oxide synthesis in experimental congestive heart failure. Cardiovasc Res 37:667-675

51. Hostetter TH, Pfeffer JM, Pfeffer MA, Dworkin LD, Braunwald E, Brenner BM (1983) Cardiorenal hemodynamics and sodium excretion in rats with myocardial infarction. Am J Physiol 245:H98-103

52. Drexler H, Toggart EJ, Glick MR, Heald J, Flaim SF, Zelis R (1986) Regional vascular adjustments during recovery from myocardial infarction in rats. J Am Coll Cardiol 8:134-142
53. Pfeffer MA, Pfeffer JM, Steinberg C, Finn P (1985) Survival after an experimental myocardial infarction: beneficial effects of longterm therapy with captopril. Circulation 72:406-412

54. Smits JF, van Krimpen C, Schoemaker RG, Cleutjens JP, Daemen MJ (1992) Angiotensin II receptor blockade after myocardial infarction in rats: effects on hemodynamics, myocardial DNA synthesis, and interstitial collagen content. J Cardiovasc Pharmacol 20:772-778

55. van Dokkum RP, Eijkelkamp WB, Kluppel AC, Henning RH, van Goor H, Citgez M, Windt WA, van Veldhuisen DJ, de Graeff PA, de Zeeuw D (2004) Myocardial infarction enhances progressive renal damage in an experimental model for cardio-renal interaction. J Am Soc Nephrol 15:3103-3110

56. Dikow R, Schmidt U, Kihm LP, Schaier M, Schwenger V, Gross ML, Katus HA, Zeier M, Hardt SE (2010) Uremia aggravates left ventricular remodeling after myocardial infarction. Am J Nephrol 32:13-22

57. Windt WA, Henning RH, Kluppel AC, Xu Y, de Zeeuw D, van Dokkum RP (2008) Myocardial infarction does not further impair renal damage in 5/6 nephrectomized rats. Nephrol Dial Transplant 23:3103-3110

58. Amann K, Tyralla K, Gross ML, Schwarz U, Tornig J, Haas CS, Ritz E, Mall G (2003) Cardiomyocyte loss in experimental renal failure: prevention by ramipril. Kidney Int 63:1708-1713

59. Amann K, Wiest G, Zimmer G, Gretz N, Ritz E, Mall G (1992) Reduced capillary density in the myocardium of uremic rats-a stereological study. Kidney Int 42:1079-1085

60. Mall G, Rambausek M, Neumeister A, Kollmar S, Vetterlein F, Ritz E (1988) Myocardial interstitial fibrosis in experimental uremia-implications for cardiac compliance. Kidney Int 33:804-811

61. Mulder P, Richard V, Bouchart F, Derumeaux G, Munter K, Thuillez C (1998) Selective ETA receptor blockade prevents left ventricular remodeling and deterioration of cardiac function in experimental heart failure. Cardiovasc Res 39:600-608

62. Dikow R, Kihm LP, Zeier M, Kapitza J, Tornig J, Amann K, Tiefenbacher C, Ritz E (2004) Increased infarct size in uremic rats: reduced ischemia tolerance? J Am Soc Nephrol $15: 1530-1536$

63. Jie KE, Verhaar MC, Cramer MJ, van der Putten K, Gaillard CA, Doevendans PA, Koomans HA, Joles JA, Braam B (2006) Erythropoietin and the cardiorenal syndrome: cellular mechanisms on the cardiorenal connectors. Am J Physiol Renal Physiol 291:F932-F944

64. van der Meer P, Lipsic E, Henning RH, Boddeus K, van der Velden J, Voors AA, van Veldhuisen DJ, van Gilst WH, Schoemaker RG (2005) Erythropoietin induces neovascularization and improves cardiac function in rats with heart failure after myocardial infarction. J Am Coll Cardiol 46:125-133

65. Garcia DL, Anderson S, Rennke HG, Brenner BM (1988) Anemia lessens and its prevention with recombinant human erythropoietin worsens glomerular injury and hypertension in rats with reduced renal mass. Proc Natl Acad Sci USA 85:6142-6146

66. Bongartz LG, Braam B, Verhaar MC, Cramer MJ, Goldschmeding R, Gaillard CA, Doevendans PA, Joles JA (2010) Transient nitric oxide reduction induces permanent cardiac systolic dysfunction and worsens kidney damage in rats with chronic kidney disease. Am J Physiol Regul Integr Comp Physiol 298:R815R823

67. Baylis C, Mitruka B, Deng A (1992) Chronic blockade of nitric oxide synthesis in the rat produces systemic hypertension and glomerular damage. J Clin Invest 90:278-281

68. Gardiner SM, Compton AM, Kemp PA, Bennett T (1990) Regional and cardiac haemodynamic effects of NG-nitro-L-arginine methyl ester in conscious, Long Evans rats. Br J Pharmacol 101:625-631 
69. Kinugawa S, Tsutsui H, Hayashidani S, Ide T, Suematsu N, Satoh S, Utsumi H, Takeshita A (2000) Treatment with dimethylthiourea prevents left ventricular remodeling and failure after experimental myocardial infarction in mice: role of oxidative stress. Circ Res 87:392-398

70. Noiri E, Nagano N, Negishi K, Doi K, Miyata S, Abe M, Tanaka T, Okamoto K, Hanafusa N, Kondo Y, Ishizaka N, Fujita T (2006) Efficacy of darbepoetin in doxorubicin-induced cardiorenal injury in rats. Nephron Exp Nephrol 104:e6-e14

71. Mihailovic-Stanojevic N, Jovovic D, Miloradovic Z, GrujicMilanovic J, Jerkic M, Markovic-Lipkovski J (2009) Reduced progression of adriamycin nephropathy in spontaneously hypertensive rats treated by losartan. Nephrol Dial Transplant 24: $1142-1150$

72. Taniyama Y, Walsh K (2002) Elevated myocardial Akt signaling ameliorates doxorubicin-induced congestive heart failure and promotes heart growth. J Mol Cell Cardiol 34:1241-1247

73. Ulu N, Buikema H, van Gilst WH, Navis G (2008) Vascular dysfunction in adriamycin nephrosis: different effects of adriamycin exposure and nephrosis. Nephrol Dial Transplant 23:18541860

74. Patten RD, Hall-Porter MR (2009) Small animal models of heart failure: development of novel therapies, past and present. Circ Heart Fail 2:138-144

75. Balakumar P, Singh AP, Singh M (2007) Rodent models of heart failure. J Pharmacol Toxicol Methods 56:1-10

76. Yang HC, Zuo Y, Fogo AB (2010) Models of chronic kidney disease. Drug Discov Today Dis Models 7:13-19

77. Liao Y, Ishikura F, Beppu S, Asakura M, Takashima S, Asanuma H, Sanada S, Kim J, Ogita H, Kuzuya T, Node K, Kitakaze M, Hori M (2002) Echocardiographic assessment of LV hypertrophy and function in aortic-banded mice: necropsy validation. Am J Physiol Heart Circ Physiol 282:H1703-H1708

78. Bayat H, Swaney JS, Ander AN, Dalton N, Kennedy BP, Hammond HK, Roth DM (2002) Progressive heart failure after myocardial infarction in mice. Basic Res Cardiol 97:206-213

79. Wu JC, Nasseri BA, Bloch KD, Picard MH, Scherrer-Crosbie M (2003) Influence of sex on ventricular remodeling after myocardial infarction in mice. J Am Soc Echocardiogr 16:1158-1162

80. Liu YH, Yang XP, Nass O, Sabbah HN, Peterson E, Carretero OA (1997) Chronic heart failure induced by coronary artery ligation in Lewis inbred rats. Am J Physiol 272:H722-H727
81. Ma LJ, Fogo AB (2003) Model of robust induction of glomerulosclerosis in mice: importance of genetic background. Kidney Int 64:350-355

82. Bing OH, Brooks WW, Robinson KG, Slawsky MT, Hayes JA, Litwin SE, Sen S, Conrad CH (1995) The spontaneously hypertensive rat as a model of the transition from compensated left ventricular hypertrophy to failure. J Mol Cell Cardiol 27:383-396

83. Inoko M, Kihara Y, Morii I, Fujiwara H, Sasayama S (1994) Transition from compensatory hypertrophy to dilated, failing left ventricles in Dahl salt-sensitive rats. Am J Physiol 267:H2471$\mathrm{H} 2482$

84. Remuzzi G, Perico N, Macia M, Ruggenenti P (2005) The role of renin-angiotensin-aldosterone system in the progression of chronic kidney disease. Kidney Int 99(Suppl):S57-65

85. Remuzzi A, Puntorieri S, Mazzoleni A, Remuzzi G (1988) Sex related differences in glomerular ultrafiltration and proteinuria in Munich-Wistar rats. Kidney Int 34:481-486

86. Tachibana H, Naga Prasad SV, Lefkowitz RJ, Koch WJ, Rockman HA (2005) Level of beta-adrenergic receptor kinase 1 inhibition determines degree of cardiac dysfunction after chronic pressure overload-induced heart failure. Circulation 111:591-597

87. de Boer RA, Pokharel S, Flesch M, van Kampen DA, Suurmeijer AJ, Boomsma F, van Gilst WH, van Veldhuisen DJ, Pinto YM (2004) Extracellular signal regulated kinase and SMAD signaling both mediate the angiotensin II driven progression towards overt heart failure in homozygous TGR(mRen2)27. J Mol Med 82:678-687

88. Ross J Jr (2002) Dilated cardiomyopathy: concepts derived from gene deficient and transgenic animal models. Circ J 66:219-224

89. Kubota T, McTiernan CF, Frye CS, Slawson SE, Lemster BH, Koretsky AP, Demetris AJ, Feldman AM (1997) Dilated cardiomyopathy in transgenic mice with cardiac-specific overexpression of tumor necrosis factor-alpha. Circ Res 81:627-635

90. Smith JD, Breslow JL (1997) The emergence of mouse models of atherosclerosis and their relevance to clinical research. J Intern Med 242:99-109

91. Huang WY, Aramburu J, Douglas PS, Izumo S (2000) Transgenic expression of green fluorescence protein can cause dilated cardiomyopathy. Nat Med 6:482-483 